\title{
Standardization parameters for cocoa pods (Theobroma cacao L.)
}

\section{Parameter standardisasi kulit buah kakao (Theobroma cacao L.)}

\author{
Nida Isti Azah*, Resmi Muchtarichie, Yoppi Iskandar \\ Fakultas Farmasi, Universitas Padjadjaran, Jawa Barat, Indonesia \\ *Corresponding author: nida.isti@gmail.com
}

\begin{abstract}
Background: Cocoa (Theobroma cacao L.) pods are a waste from chocolate production which has medicinal benefits. Cocoa pods have scientifically proved to have pharmacological activities.

Objective: Standardization of plants to be used as medicine is required to control the quality and ensure the safety, efficacy, and quality.

Methods: Data on the standardization parameters of cocoa pods were collected from journals published during the period 2010-2020 by searching in Google, Google Scholar, and Research Gate.

Results: Standardization parameters of cocoa pods consisted of macroscopic and microscopic examinations, ash content, solute concentration in solvents, phytochemical screening, and thin layer chromatography.

Conclusion: Macroscopic examination showed that the skin of cacao fruit has a brownish-yellow color and purplish red, a specific odor, and a bitter taste with four forms, namely amelonado, angoleta, cundeamor, and calabacil. Microscopic examination showed a collection of stone cells and hair covering. The moisture content of cocoa pods fulfills the requirement which is below $10 \%$. The total ash content is $5.80-7.41$, and the acid-insoluble ash content is $0.45-0.64$. The concentration of solute in water is higher than in ethanol with 22.69 and 5.21, respectively. The phytochemical screening showed that cocoa pods have flavonoids, saponins, quinones, tannins, steroids, triterpenoids, monoterpenes, and sesquiterpenes. The thin-layer chromatography indicated the presence of phenolic compounds, catechol tannins, flavonoids, and terpenoids.
\end{abstract}

Keywords: Cocoa pods, standardization, Theobroma cacao

\section{Intisari}

Latar belakang: Kulit buah kakao (Theobroma cacao L.) merupakan limbah dari produksi cokelat yang bermanfaat sebagai obat dan terbukti secara ilmiah memiliki berbagai aktivitas farmakologi.

Tujuan: Standardisasi tanaman yang akan digunakan sebagai obat berguna untuk mengontrol kualitas serta memastikan keamanan, khasiat, dan mutunya.

Metode: Data parameter standar kulit buah kakao dikumpulkan dari jurnal yang diterbitkan selama kurun waktu 2010-2020 dengan pencarian menggunakan situs pencarian seperti google, google scholar, dan researchgate.

Hasil: Parameter standardisasi kulit buah kakao meliputi pemeriksaan makroskopik, mikroskopik, nilai kadar abu, kadar zat terlarut dalam pelarut, penapisan fitokimia, dan kromatografi lapis tipis.

Kesimpulan: Pemeriksaan makroskopik, kulit buah kakao memilki warna kuning kecokelatan dan merah keunguan, bau khas, rasa pahit, dengan empat bentuk yaitu amelonado, angoleta, cundeamor, dan calabacil. Pemeriksaan mikroskopik menunjukkan adanya kumpulan sel batu dan rambut penutup. Kadar air kulit buah kakao sesuai dengan syarat yaitu berada dibawah $10 \%$. Nilai kadar abu total 5,80 - 7,41 dan kadar abu tak larut asam 0,45-0,64. Kadar zat terlarut dalam air lebih tinggi dari etanol dengan nilai masing-masing 22,69 dan 5,21. Dari hasil penapisan fitokimia kulit buah kakao menunjukkan adanya senyawa flavonoid, saponin, kuinon, tannin, steroid, triterpenoid, monoterpen dan seskuiterpen. Pada kromatografi lapis tipis menunjukkan adanya senyawa fenolik, tannin katekol, flavonoid, dan terpenoid.

Kata kunci : Kulit buah kakao, standardisasi, Theobroma cacao 


\section{Pendahuluan}

Kakao atau cokelat (Theobroma cacao L.) termasuk ke dalam suku Sterculiacea merupakan tanaman asli Amerika Selatan dan Amerika Tengah dengan habitat asli di hutan tropis Amazon. Nama Theobroma memiliki arti food of Gods, karena tanaman ini dipercaya sebagai tanaman yang berasal dari dewa. Tanaman ini, pertama kali digunakan bijinya oleh masyarakat Aztec dan Maya kuno untuk diolah menjadi minuman bernama cokelat. Seiring perkembangan zaman, kakao banyak dibudidayakan di berbagai negara (Rusconi \& Conti, 2010; Santos et al., 2014). Sampai saat ini penggunaan utama kakao adalah untuk diolah menjadi cokelat yang digunakan dalam industri minuman, makanan, kosmetika, dan lain-lain.

Pada pembuatan cokelat hanya bagian biji saja yang digunakan, sehingga bagian lain dari buah akhirnya menjadi limbah. Jika dilihat dari komposisi buah kakao yang terdiri dari 74\% kulit buah, $24 \%$ biji, dan 2\% plasenta, kulit buah merupakan bagian terbesar dan menjadi limbah terbanyak yang dihasilkan dari produksi cokelat. Limbah kulit cokelat ini jika tidak dikelola dengan baik dapat menyebabkan masalah bagi lingkungan seperti bau tidak sedap dan dapat menyebabkan penyakit Black pod disease (Suprapti \& Ramlah, 2013).

Meskipun banyak menjadi limbah, kulit buah kakao sebenarnya memiliki beragam manfaat dan salah satunya adalah sebagai obat. Di Indonesia tepatnya di bawah kaki gunung Galunggung, Tasikmalaya, masyarakat Dingga Linggarjati menggunakan kulit buah kakao secara tradisional sebagai penumbuh rambut. Penggunaan secara empiris tersebut didukung oleh hasil yang menunjukkan bahwa ekstrak etanol kulit buah kakao dapat menumbuhkan rambut pada hewan uji kelinci (Mustarichie \& Hasanah, 2019). Tidak hanya itu, kulit buah kakao juga terbukti memiliki aktivitas farmakologi lain yang terangkum dalam tabel 1.

Tabel 1. Aktivitas farmakologi kulit buah kakao

\begin{tabular}{cc}
\hline Aktivitas farmakologi & Referensi \\
\hline Analgesik & (Sari et al., 2018) \\
Antibakteri & (Nugroho et al., 2019; Singh et al., 2015) \\
Antifungal & (Rachmawaty et al., 2018) \\
Antiinflamasi & (Izzuddin \& Nurkesuma, 2015; Rahayu et al., 2020) \\
Antikerutan & (Abdul Karim et al., 2016) \\
Antioksidan & (Jusmiati et al., 2015; Umri et al., 2019) \\
\hline
\end{tabular}


Penggunaan suatu tanaman menjadi obat herbal, selain harus memiliki khasiat yaitu dengan adanya bukti ilmiah mengenai aktivitas farmakologi, juga harus memenuhi syarat obat lainnya yaitu bermutu dan terjamin keamanannya. Pada penggunaan sebagai obatan, tanaman memiliki kelemahan yaitu sulitnya mengontrol kualitas dan keamanan dari bahan yang digunakan sehingga khasiat, mutu serta profil keamanannya menjadi bervariasi (BPOM, 2019; Ghosh, 2018).

Salah satu solusi dari masalah kualitas tersebut dengan dilakukannya standardisasi. Standardisasi adalah suatu proses yang dilakukan untuk menentukan standar atau karakter yang berkaitan dengan parameter, kualitatif dan nilai kuantitatif yang memberikan jaminan terhadap kualitas, kemanjuran, keamanan dan reproduktifitas (Kunle et al., 2012).

Berdasarkan penelitian yang pernah dilakukan sebelumnya, kulit buah kakao berpotensi untuk dikembangkan menjadi Obat Herbal Terstandar (OHT), dimana diperlukan bahan baku yang terstandardisasi untuk dapat dikategorikan sebagai OHT. Oleh karena itu, pengujian parameter farmakognosi perlu dilakukan untuk memperoleh kelengkapan informasi yang berguna dalam pengembangan dan pemanfaatan kulit buah kakao sebagai obat yang memenuhi syarat obat yaitu aman, berkualitas, dan berkhasiat. Dalam kajian pustaka ini akan disajikan data mengenai pemeriksaan makroskopik, mikroskopik, kadar zat terlarut dalam pelarut (air dan etanol), kadar air, kadar abu total, kadar abu tak larut asam, uji cemaran logam, dan uji aflatoksin. Selain itu perlu diketahui kandungan dari tanaman yang akan digunakan sebagai obat karena berperan penting terhadap aktivitas farmakologi dari tanaman tersebut (Nikam et al., 2012; WHO, 2011).

\section{Metodologi penelitian}

Sumber data yang digunakan dalam penulisan artikel ini adalah jurnal yang diterbitkan selama rentang waktu 2010 - 2020 atau 10 tahun terakhir. Pencarian dilakukan dengan menelusuri situs pencarian Google, Google Scholar, dan Research Gate dengan kata kunci "Kulit Buah Kakao", "Cacao Pod", "Cacao Shell", "Cacao Skin Peel", "Pharmacognostic of Theobroma cacao", "Theobroma cacao L.", "Parameter Standar", dan "Standardisasi". Kriteria inklusi adalah jurnal mengenai aktivitas farmakologi dari kulit buah kakao dan memiliki parameter standar dari kulit buah kakao. Sedangkan, kriteria eksklusi meliputi jurnal yang tidak terverifikasi dan tidak memiliki data parameter yang diinginkan. 


\section{Hasil dan pembahasan}

\subsection{Evaluasi makroskopik}

Evaluasi makroskopik merupakan pemeriksaan pertama sebelum dilakukan pengujian lebih lanjut terhadap bahan yang digunakan. Pemeriksaan ini dilakukan dengan cepat dan sederhana karena hanya menggunakan panca indra yang dimiliki manusia. Pemeriksaan yang dilakukan meliputi bau, bentuk, karakteristik permukaan, rasa, tekstur, ukuran, dan warna. Pada saat pemeriksaan makroskopik diperlukan sampel yang sudah dipastikan kebenarannya untuk digunakan sebagai pembanding. Jika, ditemukan perbedaan yang signifikan dari sampel pembdaning maka bahan tersebut dianggap tidak memenuhi persyaratan. Tetapi, karena penilaian ini dilakukan secara subyektif, pencampuran atau pemalsuan sangat mungkin terjadi dan dibuat mirip dengan bahan asli, maka perlu untuk dilakukan evaluasi lanjutan dengan menggunakan mikroskop dan analisis fisikokimia (WHO, 2011).

Hasil pemeriksaan makroskopik dari kulit buah kakao terdapat pada tabel 2. Buah kakao memiliki ciri organoleptik yang beragam, hal ini dapat dipengaruhi oleh beberapa faktor seperti, jenis dan varietas kakao yang digunakan, lokasi penanaman, dan waktu panen. Kakao memiliki varietas yang beragam, tetapi terdapat tiga varietas utama dari kakao yaitu criollo, forastero, dan trinitario (persilangan antara criollo dan forastero) (Qin et al., 2016; Trognitz et al., 2011).

Buah kakao memiliki empat bentuk yaitu amelonado, angoleta, cundeamor, dan calabacil yang terdapat pada gambar 1. Angoleta memiliki karakteristik bergerigi dalam, berkutil, dengan persegi di ujung tangkai. Ciri amelonado permukaan kulit buah halus, alur dangkal, berbentuk seperti melon, dengan ujung tumpul dan leher seperti botol. Calabacillo memiliki bentuk yang kecil dan hampir bulat. Cundeamor berbentuk seperti angoleta dengan leher berbentuk botol (Malhotra, 2017).

Tabel 2. Evaluasi makroskopik kulit buah kakao

\begin{tabular}{|c|c|c|c|c|c|c|c|}
\hline \multirow{2}{*}{ No } & \multirow{2}{*}{ Asal tanaman } & \multicolumn{5}{|c|}{ Organoleptik } & \multirow{2}{*}{ Referensi } \\
\hline & & Warna & Bau & Bentuk & Rasa & Ukuran & \\
\hline 1. & $\begin{array}{c}\text { Rajamdanala, } \\
\text { Cipatat, Jawa } \\
\text { Barat, Indonesia }\end{array}$ & $\begin{array}{c}\text { Kuning } \\
\text { Kecokelatan }\end{array}$ & $\begin{array}{c}\text { Bau } \\
\text { Khas }\end{array}$ & - & Pahit & $\begin{array}{l}\mathrm{P}: \pm 18 \mathrm{~cm} \\
\mathrm{~L}: \pm 9 \mathrm{~cm}\end{array}$ & $\begin{array}{c}\text { (Azizah et al. } \\
\text { 2014) }\end{array}$ \\
\hline 2. & $\begin{array}{c}\text { Ea Kar, Dak Lak, } \\
\text { Vietnam }\end{array}$ & Kuning & - & Angoleta & - & - & $\begin{array}{c}\text { (Thi et al., } \\
\text { 2016) }\end{array}$ \\
\hline 3. & $\begin{array}{c}\text { Trangbom- } \\
\text { Dongnai, } \\
\text { Vietnam } \\
\end{array}$ & $\begin{array}{c}\text { Merah } \\
\text { keunguan }\end{array}$ & - & Amelonado & - & - & $\begin{array}{c}\text { (Thi et al., } \\
\text { 2016) }\end{array}$ \\
\hline
\end{tabular}




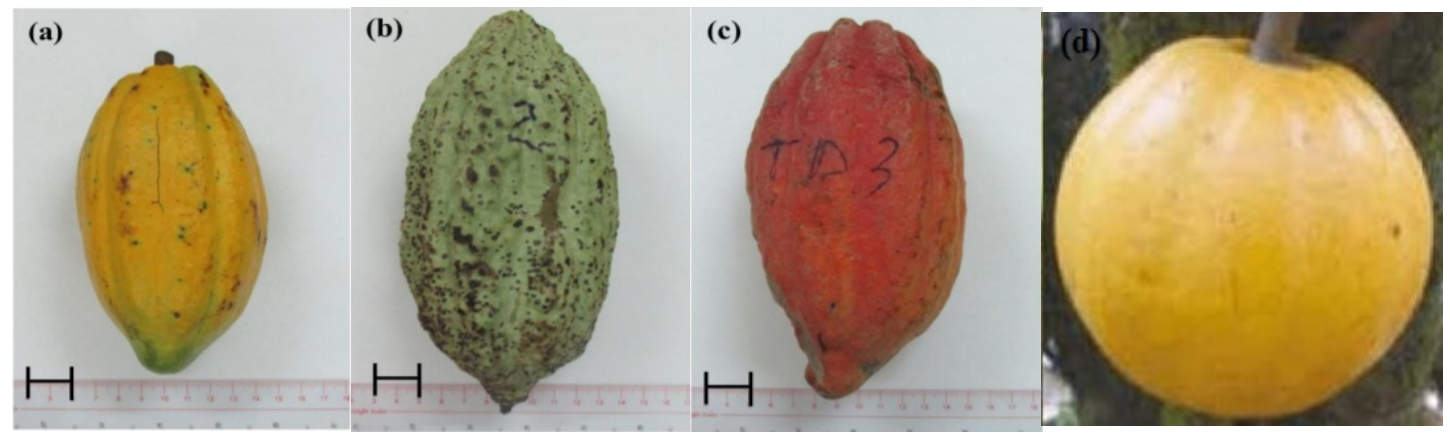

Gambar 1. Bentuk Buah Kakao (a) Amelonado, (b) Angoleta, (c) Cundeamor (d) Calabacillo (Thi et al., 2016)

\subsection{Evaluasi mikroskopik}

Evaluasi mikroskopik termasuk dalam pemeriksaan awal yang menunjang hasil pemeriksaan makroskopik. Pemeriksaan mikroskopis ini diperlukan untuk mengidentifikasi bahan yang digunakan terutama bahan-bahan yang sudah rusak atau berbentuk bubuk. Kelemahan dari pemeriksaan mikroskopik ini adalah tidak selalu dapat memberikan identifikasi lengkap. Tetapi, jika didukung pemeriksaan menggunakan metode analisis lainnya, evaluasi mikroskopik dapat memberikan bukti pendukung yang berharga (WHO, 2011). Pemeriksaan mikroskopik dilakukan dengan bantuan mikroskop binocular menggunakan pelarut kloralhidrat dengan perbesaran 100 kali. Pada kulit buah kakao pemeriksaan mikroskopik mendapatkan hasil yaitu tampak bagian epikarp yang ditunjukkan dengan adanya kumpulan sel batu pada bahan segar. Sedangkan pada serbuk simplisia kering kulit buah kakao tampak fragmen rambut penutup. Hasi uji mikroskopik kulit buah kakao terdapat di dalam tabel 3 (Azizah et al., 2014).

Tabel 3. Evaluasi mikroskopik kulit buah kakao

\begin{tabular}{|c|c|c|c|}
\hline \multirow{4}{*}{$\begin{array}{c}\text { No. } \\
1 .\end{array}$} & Asal tanaman & Mikroskopik & Referensi \\
\hline & $\begin{array}{c}\text { Rajamdanala, Cipatat, Jawa } \\
\text { Barat, Indonesia }\end{array}$ & & (Azizah et al., 2014) \\
\hline & & Kumpulan sel batu & \\
\hline & & Rambut penutup & \\
\hline
\end{tabular}




\subsection{Evaluasi fisika}

Persyaratan kadar abu total, kadar abu tak larut asam, kadar sari larut air dan kadar sari larut etanol dan kadar air ditunjukkan pada tabel 4. Kadar abu total merupakan jumlah total residu dari hasil pengabuan sampel tanaman. Sisa abu tersebut dapat berupa abu fisiologis yang berasal dari jaringan tanaman itu sendiri maupun abu non-fisiologis dari bahan asing yang menempel pada permukaan tanaman seperti tanah atau pasir. Dari pengujian kadar abu total ini didapatkan gambaran mengenai senyawa jumlah anorganik terkandung dalam sampel yang tidak habis setelah proses pengabuan. Selain itu, kadar abu juga dapat digunakan untuk memastikan kualitas, keaslian, dan kemurnian dari suatu bahan. Kadar abu kulit buah kakao asal Cipatat dan Tasikmalaya masingmasing 7,4109 dan 5,80 (Handayani et al., 2018; Mulla \& Swamy, 2010).

Tabel 4. Evaluasi fisika kulit buah kakao

\begin{tabular}{|c|c|c|c|c|c|c|}
\hline Asal & $\begin{array}{c}\text { Kadar abu } \\
\text { total }\end{array}$ & $\begin{array}{l}\text { Kadar abu } \\
\text { tidak larut } \\
\text { asam }\end{array}$ & $\begin{array}{c}\text { Kadar sari } \\
\text { larut air }\end{array}$ & $\begin{array}{c}\text { Kadar sari } \\
\text { larut etanol }\end{array}$ & Kadar air & Referensi \\
\hline $\begin{array}{c}\text { Rajamdanala, } \\
\text { Cipatat, Jawa } \\
\text { Barat, Indonesia }\end{array}$ & 7,4109 & 0,454 & 22,6917 & 5,206 & 5,2068 & $\begin{array}{c}\text { (Azizah et al., } \\
\text { 2014) }\end{array}$ \\
\hline $\begin{array}{c}\text { Kaki Gunung } \\
\text { Galunggung, } \\
\text { Tasikmalaya, } \\
\text { Jawa Barat, } \\
\text { Indonesia }\end{array}$ & 5,80 & 0,64 & - & - & 8,60 & $\begin{array}{c}\text { (Mustarichie } \\
\text { \& Hasanah, } \\
\text { 2019) }\end{array}$ \\
\hline
\end{tabular}

Kadar abu tak larut asam dilakukan menggunakan abu hasil pengujian kadar abu total yang dididihkan dalam asam klorida. Penggunaan asam klorida berujuan untuk melarutkan logam organik, sisa zat yang tidak terlarut biasanya merupakan silikat dari tanah atau pasir. Nilai kadar abu dan kadar abu tak larut asam tersebut berhubungan dengan kadar logam sehingga semakin tinggi nilai kadar abu maka kandungan logam yang terkandung juga semakin tinggi. Kadar abu tak larut asam kulit buah kakao asal Cipatat adalah 0.454 dan Tasikmalaya 0,64 (Handayani et al., 2018; Kim et al., 2013).

Kadar zat terlarut dalam suatu pelarut menyatakan jumlah pelarut yang dapat tertarik ke dalam pelarut. Nilai zat terlarut dalam suatu pelarut yang rendah dapat menunjukkan adanya penambahan bahan pakai, pemalsuan, atau adanya kesalahan selama proses pengeringan atau penyimpanan. Pada penelitian yang dilakukan terhadap kulit buah kakao asal Tasikmalaya nilai zat terlarut dalam air lebih tinggi dari etanol (Bhargava et al., 2013). 
Kadar air dalam bahan memiliki fungsi untuk memastikan kualitas sampel selama masa penyimpanan. Jika suatu bahan mengandung kadar air yang terlalu tinggi, maka jamur, bakteri, dan kapang dapat tumbuh dengan mudah sehingga dapat merusak kualitas dari bahan yang digunakan. Selain itu, kadar air juga memengaruhi bahan pada saat akan digunakan formulasi, jika mengandung kadar air yang terlalu tinggi maka akan menyebabkan kemunduran pada kualitas (Bhargava et al., 2013). Kadar air yang baik memilki persyaratan kurang dari 10\%, kulit buah kakao yang berasal dari Cipatat dan Tasikmalaya sesuai dengan persyaratan.

\subsection{Uji cemaran logam}

Logam berat adalah unsur alami yang memiliki berat atom dan massa jenis yang tinggi setidaknya 5 kali lebih besar dari air. Logam berat ini banyak terdapat di lingkungan, baik itu di udara, tanah, maupun air. Industrialisasi dan urbanisasi semakin meningkatkan kontribusi keberadaan logam berat di biosfer. Toksisitas logam berat pada tanaman bervariasi tergantung pada spesies tanaman, jenis logam, konsentrasi, bentuk kimia, komposisi tanah dan pH, karena banyak logam berat dianggap penting untuk pertumbuhan tanaman (Nagajyoti et al., 2010; Tchounwou et al., 2012).

Logam berat yang paling umum dijumpai dan dapat menimbulkan masalah jika dikonsumsi oleh manusia adalah arsen, kadmium, merkuri, dan timbal. Logam arsen (As) dapat menyebabkan masalah serius pada sistem syaraf karena otak merupakan salah satu target dari toksisitas arsenik. Arsen dapat dengan mudah melintasi sawar otak dan mendistribusikan dirinya ke berbagai bagian, tetapi akumulasi tertinggi yang diamati terdapati pada kelenjar pituitari. Keracunan arsen ini dapat memengaruhi konsentrasi hingga menyebabkan kerusakan otak (Kumar et al., 2014; Sánchez-Peña et al., 2010).

Salah satu penyakit yang disebabkan dari keracunan kadmium adalah Itai-itai disease. Penyakit ini menyerang tulang dimana kadmium menyebabkan terjadinya demineralisasi tulang, menghambat prokolagen C-proteinase, dan produksi kolagen. Kadmium kemudian dapat menyebabkan terjadinya osteoporosis, kelainan bentuk tulang, hingga patah tulang. Selain itu, kadmium juga dapat memicu terjadinya kerusakan ginjal, sistem reproduksi, dan kardiovaskular (Fagerberg et al., 2015; Pizent et al., 2012; Rafati Rahimzadeh et al., 2017).

Penyakit lain yang dapat disebabkan akibat keracunan logam berat adalah minamata disease yang disebabkan oleh merkuri. Minamata disease merupakan penyakit akibat keracunan merkuri yang dapat menyebabkan kelainann fungsi saraf. Merkuri umumnya masuk ke dalam tubuh melalui makanan dalam bentuk metilmerkuti ( $\mathrm{MeHg}$ ). Setelah masuk, merkuri akan berikatan dengan protein kemudian diedarkan oleh darah ke berbagai organ termasuk otak. Pengendapan merkuri di 
otak tersebut akan menyebabkan masalah seperti penurunan ketajaman visual, gangguan sensorik, motorik, dan pendengaran. Pada kasus yang lebih parah. Minamata disease ini dapat menyebabkan kecacatan permanen hingga kematian (Eto et al., 2010; Nogara et al., 2019).

Logam timbal $(\mathrm{Pb})$ yang masuk ke dalam tubuh dapat diekskresikan oleh urin, tetapi tidak semua timbal akan dieksreksikan. Timbal sisa tersebut akan mengikat sel darah merah, didistribusikan ke seluruh jaringan lunak tubuh, dan akhirnya terakumulasi dalam di dalam berbagai organ. Akumulasi logam timbal dalam tubuh dapat menyebabkan berbagai kerusakan pada ginjal, saraf pusat, reproduksi, dan kardiovaskular (Gillis et al., 2012; Mason et al., 2014).

Hasil pengujian dari cemaran logam yang terkandung pada kulit kakao dari beberapa daerah terdapat di dalam Tabel 5. Dari hasil pencarian yang telah dilakukan, data mengenai kandungan logam berat dalam kulit buah kakao masih sangat terbatas. Pada kulit buah kakao yang berasal dari Nigeria menunjukkan kandungan timbal yang memenuhi persyaratan. Tetapi untuk kadmium baik itu di Karibian maupun Ekuador menunjukkan nilai cemaran yang melebihi batas persyaratan.

Tabel 5. Uji cemaran logam

\begin{tabular}{|c|c|c|c|c|c|c|}
\hline No. & Asal daerah & $\begin{array}{c}\mathrm{Pb} \\
(\mathrm{ppm})\end{array}$ & $\begin{array}{c}\text { Cd } \\
(\mathbf{p p m})\end{array}$ & $\begin{array}{c}\text { As } \\
(\mathbf{p p m})\end{array}$ & $\underset{(p p m)}{\mathbf{H g}}$ & Referensi \\
\hline 1. & $\begin{array}{l}\text { Umudike, } \\
\text { Nigeria }\end{array}$ & 0.03 & - & - & - & $\begin{array}{l}\text { (Olim et al., } \\
\text { 2020) }\end{array}$ \\
\hline 2. & $\begin{array}{c}\text { Trinidad dan } \\
\text { Tobago, } \\
\text { Karibian }\end{array}$ & - & $0,53-4,49$ & - & - & $\begin{array}{c}\text { (Ramtahal et al., } \\
\text { 2016) }\end{array}$ \\
\hline \multirow[t]{2}{*}{3.} & $\begin{array}{c}\text { Esmeraldas, } \\
\text { Ecuador }\end{array}$ & - & $0,34-1,96$ & - & - & $\begin{array}{c}\text { (Barraza et al., } \\
\text { 2017) }\end{array}$ \\
\hline & Syarat & $\leq 10$ & $\leq 0,3$ & $\leq 5$ & $\leq 0,5$ & (BPOM, 2019) \\
\hline
\end{tabular}

\subsection{Uji aflatoksin}

Aflatoksin adalah mikotoksin yaitu metabolit sekunder sangat beracun, teratogenik, dan karsinogenik yang diproduksi oleh jamur genus Aspergillus. Aflatoksin dapat mencemari bahan makanan dan apabila dikonsumsi oleh manusia dapat menyebabkan masalah kesehatan serius. Terdapat berbagai tipe aflatoksin, tetapi B1, B2, G1, dan G2 merupakan spesies yang paling banyak mencemari bahan makanan. Aflatoksin B1 merupakan yang paling berbahaya karena di hati akan diaktifkan oleh enzim sitokrom p450, kemudian dikonversi menjadi AFB1-8,9-epoksida, yang menghasilkan efek karsinogenik dengan menciptakan peroksidase di dalam ginjal. Dari hasil pengujian aflatoksin kulit buah kakao asal Tafo, Ghana menunjukkan nilai yang kecil dan tidak melebihi batas yang dipersyaratkan (Lee et al., 2015; Ma et al., 2015). 
Nilai persyaratan aflatoksin paling umum mengatur kadar cemaran aflatoksin B1 dan aflatoksin total. Di Indonesia sendiri batas aflatoksin B1 yang diperbolehkan untuk penggunaan tanaman sebagai obat adalah $\leq 5 \mu \mathrm{g} / \mathrm{kg}$ dan aflatoksin total sebesar kurang dari $\leq 20 \mu \mathrm{g} / \mathrm{kg}$. Mengacu pada persyaratan tersebut kulit buah kakao yang berasal dari Ghana memenuhi persyaratan dengan aflatoksin B1 sebesar 0,04 $\mu \mathrm{g} / \mathrm{kg}$, aflatoksin B2 sebesar 0,4 $\mu \mathrm{g} / \mathrm{kg}$, dan aflatoksin G1 dan G2 sejumlah 0,6 $\mu \mathrm{g} / \mathrm{kg}$ (Adamafio et al., 2011).

\subsection{Penapisan fitokimia}

Penapisan fitokimia berguna untuk mengetahui golongan senyawa apa saja yang terkandung di dalam suatu tanaman dan berguna untuk menelusuri potensi farmakologinya. Pengujian ini biasanya dilakukan dengan menggunakan metode dan reagen sederhana. Berdasarkan hasil penelusuran data yang dilakukan, dapat ditunjukkan adanya variasi kandungan dari kulit buah kakao (tabel 6). Pada pengujian alkaloid kulit buah kakao yang berasal dari Jawa Barat, Sulawesi Barat, Sulawesi Selatan, dan Sumatera tidak mengandung senyawa tersebut. Perbedaan kandungan senyawa tersebut dapat disebabkan oleh beberapa faktor seperti usia dan waktu panen tanaman serta pelarut dan metode ekstraksi yang digunakan (Kigigha \& Zige, 2013).

Tabel 6. Penapisan fitokimia kulit buah kakao

\begin{tabular}{|c|c|c|c|c|c|c|c|c|c|c|c|c|c|}
\hline No. & Asal & Pelarut & Metode & A & $\mathbf{F}$ & Sp & $\mathbf{P}$ & $\mathbf{T}$ & $\mathbf{K}$ & MS & $\mathbf{S t}$ & $\mathrm{Tr}$ & Referensi \\
\hline 1. & $\begin{array}{l}\text { Tasikmalaya, } \\
\text { Jawa Barat, } \\
\text { Indonesia }\end{array}$ & Etanol & Maserasi & - & + & + & + & + & - & + & + & + & $\begin{array}{c}\text { (Mustarichie \& } \\
\text { Hasanah, } \\
\text { 2019) }\end{array}$ \\
\hline 2. & $\begin{array}{c}\text { Poliwalimdanar, } \\
\text { Sulawesi Barat, } \\
\text { Indonesia }\end{array}$ & Metanol & Maserasi & - & - & + & $\begin{array}{l}\mathrm{N} \\
\mathrm{A}\end{array}$ & + & $\begin{array}{l}\mathrm{N} \\
\mathrm{A}\end{array}$ & NA & - & + & $\begin{array}{c}\text { (Pappa et al., } \\
\text { 2019) }\end{array}$ \\
\hline 3. & $\begin{array}{c}\text { Toraja Utara, } \\
\text { Sulawesi Selatan, } \\
\text { Indonesia }\end{array}$ & Metanol & Maserasi & - & - & + & $\begin{array}{l}\mathrm{N} \\
\mathrm{A}\end{array}$ & + & $\begin{array}{l}\mathrm{N} \\
\mathrm{A}\end{array}$ & NA & - & + & $\begin{array}{l}\text { (Pappa et al., } \\
\text { 2019) }\end{array}$ \\
\hline 4. & $\begin{array}{l}\text { Sumatera, } \\
\text { Indonesia }\end{array}$ & Metanol & Maserasi & - & - & - & + & $\begin{array}{l}\mathrm{N} \\
\mathrm{A}\end{array}$ & $\begin{array}{l}\mathrm{N} \\
\mathrm{A}\end{array}$ & NA & + & + & $\begin{array}{l}\text { (Sihombing et } \\
\text { al., 2015) }\end{array}$ \\
\hline 5. & $\begin{array}{c}\text { Rajamandala, } \\
\text { Cipatat, Jawa } \\
\text { Barat, Indonesia }\end{array}$ & Metanol & Soxhlet & + & + & + & + & + & + & + & - & - & $\begin{array}{c}\text { (Azizah et al., } \\
\text { 2014) }\end{array}$ \\
\hline 6. & $\begin{array}{c}\text { Lawe Loning, } \\
\text { Lawe Sigala-Gala, } \\
\text { Aceh, Indonesia }\end{array}$ & Metanol & Maserasi & + & + & + & + & $\begin{array}{l}\mathrm{N} \\
\mathrm{A}\end{array}$ & $\begin{array}{l}\mathrm{N} \\
\mathrm{A}\end{array}$ & NA & - & - & $\begin{array}{c}\text { (Ginting et al., } \\
\text { 2019) }\end{array}$ \\
\hline
\end{tabular}

Deteksi menggunakan KLT diperlihatkan pada tabel 7 dan gambar 2. Pada KLT dengan eluen toluen:aseton:asam formiat (3:3:0,5) dengan pereaksi Liebermann-Burchard menimbulkan warna mantap dengan adanya fluoresensi hijau atau biru pada pembacaan di lampu UV 366 yang 
menunjukkan adanya senyawa terpenoid. Penyemprotan bercak dengan menggunakan Vanilin- $\mathrm{HCl}$ menghasilkan warna merah yang menunjukkan adanya senyawa tannin katekol. Adanya senyawa flavonoid ditunjukkan dengan adanya fluoresensi kuning di bawah lampu UV 366 setelah disemprot dengan $\mathrm{AlCl}_{3}$. Pada KLT dengan menggunakan eluen butanol : asam asetat glasial :air (4:1:5) noda berfluorosensi di UV 254 dan 366 nm menunjukkan adanya gugus kromofor dan ikatan rangkap terkonjugasi. Kemudian visualisasi menggunakan pereaksi $\mathrm{FeCl}_{3}$ menunjukkan adanya senyawa fenolik yang ditandai dengan warna noda hijau kebiruan (Loppies \& Yumas, 2014).

Tabel 7. Kromatogram ekstrak kulit buah kakao

\begin{tabular}{|c|c|c|c|c|c|c|}
\hline No. & Asal Daerah & Fase Diam & Eluen & Pereaksi & Hasil & Referensi \\
\hline 1. & $\begin{array}{l}\text { Sengkang, Sulawesi } \\
\text { Selatan }\end{array}$ & $\begin{array}{l}\text { Silika Gel } \\
\text { GF }_{254}\end{array}$ & $\begin{array}{c}\text { Butanol : Asam } \\
\text { Asetat Glasial : } \\
\text { Air }(4: 1: 5)\end{array}$ & $\mathrm{FeCl}_{3}$ & $\begin{array}{c}\text { Senyawa } \\
\text { Fenolik }\end{array}$ & (Mita, 2015) \\
\hline 2. & $\begin{array}{c}\text { Makassar, Sulawesi } \\
\text { Selatan }\end{array}$ & $\begin{array}{l}\text { Silika Gel } \\
\text { GF }_{254}\end{array}$ & $\begin{array}{c}\text { Toluen : } \\
\text { Aseton : Asam } \\
\text { Formiat } \\
(3: 3: 0,5)\end{array}$ & $\begin{array}{c}\text { Liebermann- } \\
\text { Burchard } \\
\text { Vanilin-HCl } \\
\mathrm{AlCl}_{3} \\
\end{array}$ & $\begin{array}{c}\text { Terpenoid } \\
\text { Tanin Katekol } \\
\text { Flavonoid }\end{array}$ & $\begin{array}{l}\text { (Loppies \& } \\
\text { Yumas, } \\
\text { 2014) }\end{array}$ \\
\hline
\end{tabular}

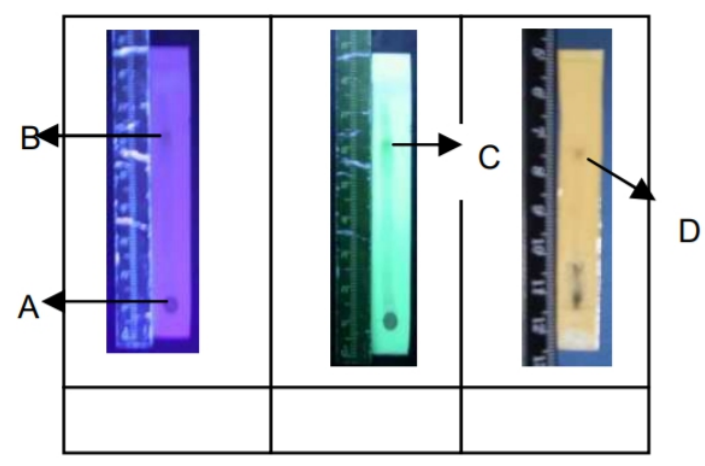

Gambar 2. Kromatografi Lapis Tipis Eluen Butanol : Asam Asetat Glasial : Air ( 4:1:5) (a) tempat penotolan; (b) noda tampak pada UV 366; (c) noda tampak pada UV 254;(d) noda tampak $\mathrm{FeCl}_{3}$ (Mita, 2015)

Senyawa flavonoid yang terkandung di dalam kulit buah kakao dapat berhubungan dengan adanya aktivitas antioksidan sebab flavonoid merupakan senyawa yang sangat tertarik pada radikal peroksida lipid sehingga menghambat proses oksidasi lipid. Selain memiliki aktivitas sebagai antioksidan, flavonoid juga diduga memilki aktivitas sebagai antibakteri, analgesik, antiinflamasi, dan antikanker (Abdul Karim et al., 2016; Mansourabadi et al., 2015; Wang et al., 2013). Pada penelitian lebih lanjut yang dilakukan oleh Abdul Karim et al., (2014) menggunakan LC-MS flavonoid yang terkandung di dalam kulit buah kakao adalah rhamnetin, flavon, kaempferol, linarin, dan acacetin. 
Saponin merupakan senyawa glikosida yang memilki kemampuan untuk menghasilkan buih dan menghemolisis darah. Senyawa saponin memiliki dua sisi yaitu polar dan nonpolar yang memiliki permukaan aktif. Pada saat pengocokan dengan air, saponin akan membentuk misel yang tampak seperti buih. Hasil positif dari pengujian saponin adalah buih yang bertahan selama kurang lebih 10 menit dan tetap ada setelah penambahan HCl. Saponin memiliki aktivitas sebagai antimikroba, antidiabetik, sitotoksik, antispasmodik, antioksidan, antihelmintik (Ayaz et al., 2014; Rachman et al., 2015).

\section{Kesimpulan}

Berdasarkan hasil pemeriksaan parameter standardisasi kulit buah kakao (Theobroma cacao L.) dapat ditarik kesimpulan yaitu padapemeriksaan makroskopik, kulit buah kakao memilki warna kuning kecokelatan dan merah keunguan, bau khas, rasa pahit, dengan empat bentuk yaitu amelonado, angoleta, cundeamor, dan calabacil. Pemeriksaan mikroskopik menunjukkan adanya kumpulan sel batu dan rambut penutup. Kadar air kulit buah kakao sesuai dengan syarat yaitu berada dibawah 10\%. Nilai kadar abu total 5,80 - 7,40 dan kadar abu tak larut asam 0,45 - 0,64. Kadar zat terlarut dalam air lebih tinggi dari etanol dengan nilai masing-masing 22,69 dan 5,21. Dari hasil penapisan fitokimia kulit buah kakao menunjukkan adanya senyawa flavonoid, saponin, kuinon, tannin, steroid, triterpenoid, monoterpen dan seskuiterpen. Pada kromatografi lapis tipis menunjukkan adanya senyawa fenolik, tannin katekol, flavonoid, dan terpenoid.

\section{Daftar pustaka}

Abdul Karim, A., Azlan, A., Ismail, A., Hashim, P., Abd Gani, S. S., Zainudin, B. H., \& Abdullah, N. A. (2016). Efficacy of cocoa pod extract as antiwrinkle gel on human skin surface. J Cosmet Dermatol, 15(3), 283295. doi:10.1111/jocd.12218

Adamafio, N. A., Ayombil, F., \& Tano-Debrah, K. (2011). Microbial detheobromination of cocoa (Theobroma cacao) pod Husk. Asian. J. Biochem, 6, 200-207. doi:10.3923/ajb.2011.200.207

Ayaz, M., Junaid, M., Subhan, F., Ullah, F., Sadiq, A., Ahmad, S., Imran, M., Kamal, Z., Hussain, S., \& Shah, S. M. (2014). Heavy metals analysis, phytochemical, phytotoxic and anthelmintic investigations of crude methanolic extract, subsequent fractions and crude saponins from Polygonum hydropiper L. BMC complementary and alternative medicine, 14, 465. doi:10.1186/1472-6882-14-465

Azizah, D., Kumolowati, E., \& Faramayuda, F. (2014). Penetapan kadar flavonoid metode AlCl3 pada ekstrak metanol kulit buah kakao (Theobroma cacao L.). Kartika Jurnal Ilmiah Farmasi, 2. doi:10.26874/kjif.v2i2.14

Barraza, F., Schreck, E., Lévêque, T., Uzu, G., López, F., Ruales, J., Prunier, J., Marquet, A., \& Maurice, L. (2017). Cadmium bioaccumulation and gastric bioaccessibility in cacao: A field study in areas impacted by oil activities in Ecuador. Environmental Pollution, 229, 950-963. doi:https://doi.org/10.1016/i.envpol.2017.07.080

Bhargava, V., Saluja, A. K., \& Dholwani, K. (2013). Detection of Heavy Metal Contents and Proximate Analysis of roots of Anogeissus latifolia. 1, 61.

BPOM. (2019). Peraturan BPOM Nomor 32 Tahun 2019 tentang Persyaratan Keamanan dan Mutu Obat Tradisional. Jakarta: BPOM 
Eto, K., Marumoto, M., \& Takeya, M. (2010). The pathology of methylmercury poisoning (Minamata disease): The 50th Anniversary of Japanese Society of Neuropathology. Neuropathology, 30(5), 471-479. doi:10.1111/j.1440-1789.2010.01119.x

Fagerberg, B., Barregard, L., Sallsten, G., Forsgard, N., Ostling, G., Persson, M., Borné, Y., Engström, G., \& Hedblad, B. (2015). Cadmium exposure and atherosclerotic carotid plaques--results from the Malmö diet and Cancer study. Environ Res, 136, 67-74. doi:10.1016/j.envres.2014.11.004

Ghosh, D. (2018). Quality issues of herbal medicines: internal and external factors. International Journal of Complementary \& Alternative Medicine, 11. doi:10.15406/ijcam.2018.11.00350

Gillis, B. S., Arbieva, Z., \& Gavin, I. M. (2012). Analysis of lead toxicity in human cells. BMC Genomics, 13, 344. doi:10.1186/1471-2164-13-344

Ginting, B., Prihutama, I., Saidi, N., \& Astryna, S. (2019). Isolation and activity antioxidant test of cocoa pod husk ethyl asetat extracts (Theobroma cacao L). Jurnal Natural, 19, 49-53. doi:10.24815/jn.v19i2.12568

Handayani, S., Kadir, A., \& Masdiana, M. (2018). Profil fitokimia dan pemeriksaan farmakognostik daun antinganting (Acalypha indica. L). Jurnal Fitofarmaka Indonesia, 5, 258-265. doi:10.33096/jffi.v5i1.317

Izzuddin, A., \& Nurkesuma, A. (2015). The potential of cocoa (Theobroma cacao l.) pods extract in periodontal dressing to rabbit gingival wound healing.

Jusmiati, J., Rusli, R., \& Rijai, L. (2015). Aktivitas Antioksidan Kulit Buah Kakao Masak dan Kulit Buah Kako Muda. Jurnal Sains dan Kesehatan, 1, 34-39. doi:10.25026/jsk.v1i1.13

Kigigha, L. T., \& Zige, D. V. (2013). Activity of chromolaena odorata on enteric and superficial etiologic bacterial agents.

Kim, D., Kim, B., Yun, E., Kim, J., Chae, Y., \& Park, S. (2013). Statistical quality control of total ash, acid-insoluble ash, loss on drying, and hazardous heavy metals contained in the component medicinal herbs of "Ssanghwatang", a widely used oriental formula in Korea. Journal of Natural Medicines, 67(1), 27-35. doi:10.1007/s11418-012-0640-4

Kumar, S. R., Priyatharshni, S., Babu, V. N., Mangalaraj, D., Viswanathan, C., Kannan, S., \& Ponpandian, N. (2014). Quercetin Conjugated Superparamagnetic Magnetite Nanoparticles for In-vitro Analysis of Breast Cancer Cell Lines for Chemotherapy Applications. J Colloid Interface Sci, 436, 234-242. doi:10.1016/j.jcis.2014.08.064

Kunle, O., Folashade, Egharevba, H., Omoregie, \& Ochogu, P. (2012). Standardization of herbal medicines -A review. International Journal of Biodiversity and Conservation, 4, 101-112.

Lee, J., Her, J. Y., \& Lee, K. G. (2015). Reduction of aflatoxins $\left(B_{1}, B_{2}, G_{1}\right.$, and $\left.G_{2}\right)$ in soybean-based model systems. Food Chem, 189, 45-51. doi:10.1016/j.foodchem.2015.02.013

Loppies, J. E., \& Yumas, M. (2014). Ekstraksi Komponen Aktif Kulit Buah Kakao dan Pemanfaatannya sebagai Bahan Pengawer Alami Pada Produk Makanan. Jurnal Industri Hasil Perkebunan, 9(2), 9.

Ma, X., Wang, W., Chen, X., Xia, Y., Duan, N., Wu, S., \& Wang, Z. (2015). Selection, characterization and application of aptamers targeted to Aflatoxin B2. Food Control, 47, 545-551. doi:https://doi.org/10.1016/i.foodcont.2014.07.037

Malhotra, S. (2017). Genetic resources of cocoa (Theobroma cacao L.) and its utilization- An Appraisal. Indian Journal of Genetics and Plant Breeding, 77, 199-213. doi:10.5958/0975-6906.2017.00027.X

Mansourabadi, A. H., Sadeghi, H. M., Razavi, N., \& Rezvani, E. (2015). Anti-inflammatory and Analgesic Properties of Salvigenin, Salvia officinalis Flavonoid Extracted. Advanced Herbal Medicine, 1, 31-41.

Mason, L. H., Harp, J. P., \& Han, D. Y. (2014). Pb neurotoxicity: neuropsychological effects of lead toxicity. Biomed Res Int, 2014, 840547. doi:10.1155/2014/840547

Mita, N. (2015). Formulasi Krim dari Kulit Buah Kakao (Theobroma cacao L.) Berkhasiat Antioksidan. Journal of Tropical Pharmacy and Chemistry, 3, 12-21. doi:10.25026/jtpc.v3i1.83

Mulla, S., \& Swamy, P. (2010). Preliminary Pharmacognostical And Phytochemical Evaluation of Portulaca quadrifida Linn. International Journal of PharmTech Research, 2.

Mustarichie, R., \& Hasanah, A. N. (2019). Anti-alopecia activity of waste cacao (Theobroma cacao L.) peels. Drug Invention Today, 11(9), 6.

Nagajyoti, P. C., Lee, K. D., \& Tvm, S. (2010). Heavy metals, occurrence and toxicity for plants: A review. Environmental Chemistry Letters, 8(3), 199-216. Environmental Chemistry Letters, 8, 199-216. doi:10.1007/s10311-010-0297-8

Nikam, P. H., Kareparamban, J., Jadhav, A., \& Kadam, V. (2012). Future trends in standardization of herbal drugs. Journal of Applied Pharmaceutical Science, 2, 38-44. doi:10.7324/JAPS.2012.2631 
Nogara, P. A., Oliveira, C. S., Schmitz, G. L., Piquini, P. C., Farina, M., Aschner, M., \& Rocha, J. B. T. (2019). Methylmercury's chemistry: From the environment to the mammalian brain. Biochimica et Biophysica Acta (BBA) - General Subjects, 1863(12), 129284. doi:https://doi.org/10.1016/j.bbagen.2019.01.006

Nugroho, S., Rukmo, M., Prasetyo, E., \& Yuanita, T. (2019). Antibakteri Ekstrak Kulit Buah Kakao (Theobroma cacao) 6,25\% dan NaOCl 2,5\% Terhadap Bakteri Streptococcus sanguinis. Conservative Dentistry Journal, 9, 19. doi:10.20473/cdj.v9i1.2019.19-21

Olim, D., Afu, S., Adie, P., \& Akpa, E. (2020). Adsorption kinetics of Copper, Lead and Zinc by Cow Dung, Poultry Manure and Cocoa (Theobroma Cacao) Pod. 2020.

Pappa, S., Jamaluddin, A. W., \& Ris, A. (2019). Kadar tanin pada kulit buah kakao (Theobroma cacao 1.) Kabupaten Poliwalimandar dan Toraja Utara. CAKRA KIMIA (Indonesian E-Journal of Applied Chemistry)(2), $\quad 92-101 \% \mathrm{~V} \quad 107$. https://ojs.unud.ac.id/index.php/cakra/article/view/56181

Pizent, A., Tariba, B., \& Živković, T. (2012). Reproductive toxicity of metals in men. Arh Hig Rada Toksikol, 63 Suppl 1, 35-46. doi:10.2478/10004-1254-63-2012-2151

Qin, X.-W., Lai, J.-X., Tan, L.-H., Hao, C.-Y., Li, F.-P., He, S.-Z., \& Song, Y.-H. (2016). Characterization of volatile compounds in Criollo, Forastero and Trinitario cocoa seeds ( Theobroma cacao L.) in China. International Journal of Food Properties, 20. doi:10.1080/10942912.2016.1236270

Rachman, A., Wardatun, S., \& Weandarlina, I. Y. (2015). Isolasi dan Identifikasi Senyawa Saponin Ekstrak Metanol Daun Binahong (Anredera cordifolia (Ten.) Steenis). Jurnal MIPA, 1(1), 6.

Rachmawaty, M• nisa, A., Hasri, Pagarra, H., Hartati, \& Maulana, Z. (2018). Active Compounds Extraction of Cocoa Pod Husk (Thebroma Cacao l.) and Potential as Fungicides.

Rafati Rahimzadeh, M., Rafati Rahimzadeh, M., Kazemi, S., \& Moghadamnia, A.-A. (2017). Cadmium toxicity and treatment: An update. Caspian journal of internal medicine, 8(3), 135-145. doi:10.22088/cjim.8.3.135

Rahayu, Y. C., Yuwono, B., \& Wandansari, A. (2020). The effectiveness ofproanthocyanidins cacao pods (Theobroma cacao L.) on increasing socket epithelial thickness post toothextraction in wistar rats. Journal of Dentomaxillofacial Science, 5(1), 5.

Ramtahal, G., Chang-Yen, I., Bekele, I., Bekele, F., Wilson, L., Maharaj, K., \& Harrynanan, L. (2016). Relationships between Cadmium in Tissues of Cacao Trees and Soils in Plantations of Trinidad and Tobago. Food and Nutrition Sciences, 07, 37-43. doi:10.4236/fns.2016.71005

Rusconi, M., \& Conti, A. (2010). Theobroma cacao L., the Food of the Gods: a scientific approach beyond myths and claims. Pharmacol Res, 61(1), 5-13. doi:10.1016/j.phrs.2009.08.008

Sánchez-Peña, L. C., Petrosyan, P., Morales, M., González, N. B., Gutiérrez-Ospina, G., Del Razo, L. M., \& Gonsebatt, M. E. (2010). Arsenic species, AS3MT amount, and AS3MT gene expression in different brain regions of mouse exposed to arsenite. Environ Res, 110(5), 428-434. doi:10.1016/j.envres.2010.01.007

Santos, R. X., Oliveira, D. A., Sodré, G. A., Gosmann, G., Brendel, M., \& Pungartnik, C. (2014). Antimicrobial activity of fermented Theobroma cacao pod husk extract. Genet Mol Res, 13(3), 7725-7735. doi:10.4238/2014.September.26.10

Sari, Y. L., Wisudanti, D. D., \& Shodikin, M. A. (2018). The Analgesic Effectiveness Test of Cocoa Husk (Theobroma cacao L.) Extract to Licking Time of Mice Induced by Formalin. JOURNAL AMS(2), 8389\%V 84. doi:10.19184/ams.v4i2.6328

Sihombing, J. R., Dharma, A., Chaidir, Z., Almahdy, A., Fachrial, E., \& Munaf, E. (2015). Phytochemical screening and antioxidant activities of 31 fruit peel extract from Sumatera, Indonesia. 7, 190-196.

Singh, N., Datta, S., Dey, A., Chowdhury, A. R., \& Abraham, J. (2015). Antimicrobial activity and cytotoxicity of Theobroma cacao extracts. Der Pharmacia Lettre, 7, 287-294.

Suprapti, \& Ramlah, S. (2013). Pemanfaatan Kulit Buah Kakao Untuk Briket Arang. Jurnal Biopropal Industri, $4(2), 7$.

Tchounwou, P. B., Yedjou, C. G., Patlolla, A. K., \& Sutton, D. J. (2012). Heavy metal toxicity and the environment. Experientia supplementum (2012), 101, 133-164. doi:10.1007/978-3-7643-8340-4_6

Thi, L., Ha, V., Hang, P., Everaert, H., Rottiers, H., Lam, A., Dung, T., Hồng, P., Phuoc, D., Toan, H., Dewettinck, K., \& Messens, K. (2016). Characterization of leaf, flower, and pod morphology among vietnamese cocoa varieties (Theobroma cacao L.). Pakistan Journal of Botany, 48, 2375-2383.

Trognitz, B., Scheldeman, X., Hansel-Hohl, K., Kuant, A., Grebe, H., \& Hermann, M. (2011). Genetic population structure of cacao plantings within a young production area in Nicaragua. PLoS One, 6(1), e16056. doi:10.1371/journal.pone.0016056 
Umri, R., Maulana, I., \& Ginting, B. (2019). Antioxidant and cytotoxic activity of ethyl asetat extracts of cocoa pod husk ( Theobroma cacao L). IOP Conference Series: Earth and Environmental Science, 364, 012026. doi:10.1088/1755-1315/364/1/012026

Wang, C. Z., Calway, T. D., Wen, X. D., Smith, J., Yu, C., Wang, Y., Mehendale, S. R., \& Yuan, C. S. (2013). Hydrophobic flavonoids from Scutellaria baicalensis induce colorectal cancer cell apoptosis through a mitochondrial-mediated pathway. Int J Oncol, 42(3), 1018-1026. doi:10.3892/ijo.2013.1777

WHO. (2011). Quality Control Methods for Herbal Materials. from WHO press 